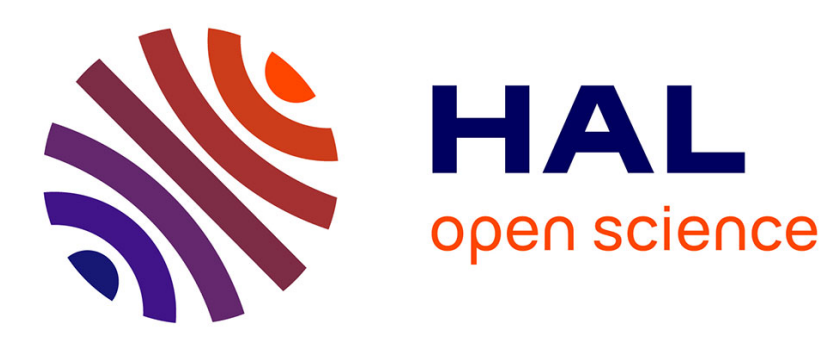

\title{
Optical fundamental band-gap energy of semiconductors by photoacoustic spectroscopy
}

\author{
J. Caetano de Souza, A. Ferreira da Silva, H. Vargas
}

\section{To cite this version:}

J. Caetano de Souza, A. Ferreira da Silva, H. Vargas. Optical fundamental band-gap energy of semiconductors by photoacoustic spectroscopy. Journal de Physique IV Proceedings, 1994, 04 (C7), pp.C7-129-C7-132. 10.1051/jp4:1994731 . jpa-00253259

\section{HAL Id: jpa-00253259 https://hal.science/jpa-00253259}

Submitted on 1 Jan 1994

HAL is a multi-disciplinary open access archive for the deposit and dissemination of scientific research documents, whether they are published or not. The documents may come from teaching and research institutions in France or abroad, or from public or private research centers.
L'archive ouverte pluridisciplinaire HAL, est destinée au dépôt et à la diffusion de documents scientifiques de niveau recherche, publiés ou non, émanant des établissements d'enseignement et de recherche français ou étrangers, des laboratoires publics ou privés. 


\title{
Optical fundamental band-gap energy of semiconductors by photoacoustic spectroscopy
}

J. Caetano de Souza, A. Ferreira da Silva* and H. Vargas**

Instituto de Física, Universidade Federal da Bahia, Campus da Federação, 40210-340 Salvador, Bahia, Brazil and Hospital São Rafael, Av. São Rafael, 2152 São Marcos, 41200 Salvador, Bahia, Brazil

* Instituto de Física, UFBA, Campus da Federação, 40210-340 Salvador, Bahia, Brazil and Laboratório Associado de Sensores e Materiais - LAS/INPE, C.P. 515, 1220I-970, Sáo José dos Compos, SP, Brazil

** Departamento de Física, Centro de Investigación y Estudos Avanzados del IPN, A.P. 14-740, México D.F. 070000, México and Instituto de Física, UNICAMP, C.P. 6165, 13081-970 Campinas, SP, Brazil

\begin{abstract}
The optical band-gap energy of the semiconductors GaAs, CdSe, Cds, Znse and $\mathrm{Si}$ doped with $P$ at a concentration of $4 \times 10^{18} \mathrm{~cm}^{-3}$, are obtained by photoacoustic spectroscopy technique. Excellent agreements are found with the values recorded in the literature.
\end{abstract}

\section{INTRODUCTION}

The investigation of optical absorption in semiconductors by photoacoustic spectroscopy (PAS) has been a subject of intensive interest in recent years ${ }^{1-4}$, mainly of its importance as a guide in the studies of the band-gap energy which is an important parameter in transistor design ${ }^{4,5}$.

In this work, we present the results of optical absorption measurements of some III-V and II-VI semiconductors at room temperature. We have used the well-known PAS to compute the optical band-gap energies of GaAs, CaSe, CaS, ZnSe and Si doped with $\mathrm{P}$, i.e., Si:P system, measured by the microphonic technique in the wavelenght region around the fundamental absorption edge ${ }^{1-4,6}$. 


\subsection{RESULTS OF PA SPECTRA}

In Figure 1 we show the photoacoustic spectra for a range of intrinsic direct-band semiconductors in powder form, i.e., GaAs, cdse, cds, znse and also for the extrinsic indirect band semiconducting specimen $\mathrm{Si}$ doped with $\mathrm{P}$ impurity atomos at $a$ concentration of $\mathrm{N}=4 \times 10^{18} \mathrm{~cm}^{-3}$. The spectra are obtained at room temperature. The Si:P system was chosen due to its importance as a good device as well as an ideal prototype for studies of effects of disorder ${ }^{7}$. Results for the presented range of energies are in satisfactory agreement with other measurements ${ }^{1-4,6}$.

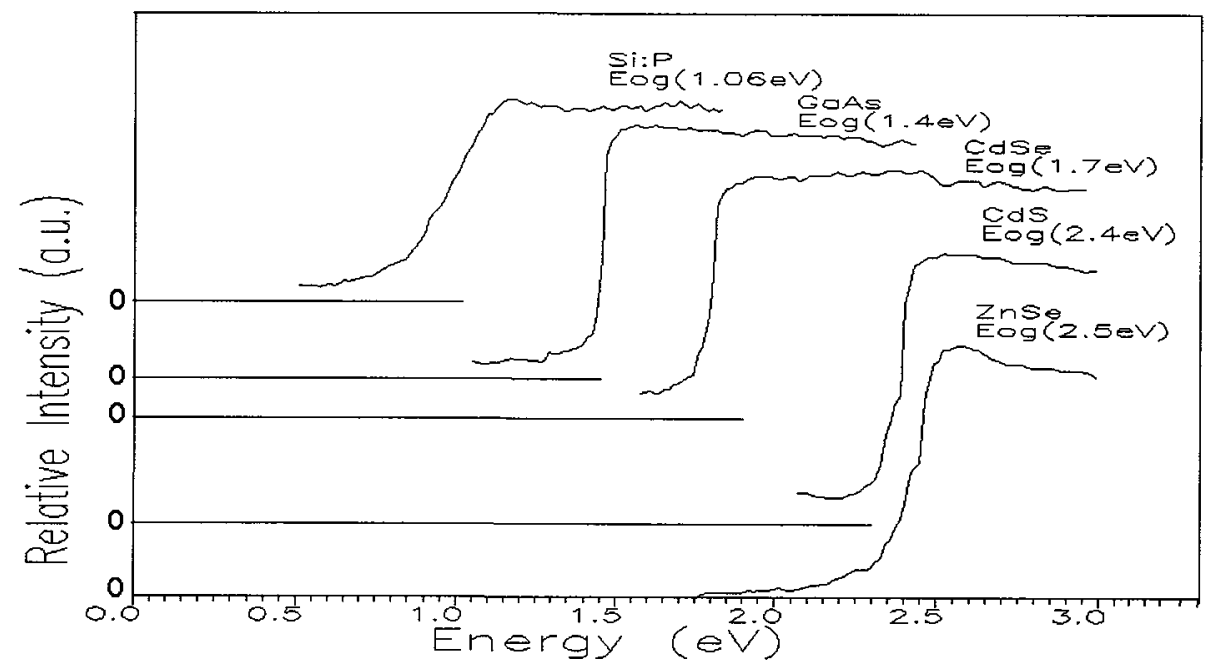

FIGURE 1 - ROOM TEMPERATURE PHOTOACOUSTIC SPECTRA 
The optical band-gap energy is obtained by a spectral shape that is fitted to the absorption spectra of the PA intensity, i.e., Figure 1, as a function of the photon energy $h \omega$. It is represented by the following equation ${ }^{8,9}$,

$\alpha(\hbar \omega)=\lambda \hbar \omega\left[\Gamma^{2}+\left(\hbar \omega-\hbar \omega_{0}\right)^{2}\right]^{-1 / 2}+\lambda_{0}$,

where $\Gamma$ is a damping parameter and $\lambda_{0}$ is a constant added to correct the possible error on the origin of the data. The values obtained for the optical band-gap $\mathrm{E}_{\text {og }}$ are: $\mathrm{E}_{\text {og }}(\mathrm{GaAs})=1.4 \mathrm{eV}, \mathrm{E}_{\mathrm{og}}$ (CdSe) $1.7 \mathrm{eV}, \mathrm{E}_{\text {og }}(\mathrm{CdS})=2.4 \mathrm{eV}$ and $\mathrm{E}_{\text {og }}(\mathrm{ZnSe})=2.5 \mathrm{eV}$. They are in excellent agreements with the values recorded in the literature ${ }^{1,3,4,6,8-12}$.

For the $\mathrm{Si}: \mathrm{P}$ system we found $\mathrm{E}_{\text {og }}(\mathrm{Si}: \mathrm{P})=1.06 \mathrm{eV}$, in agreement with recent photoluminescence excitation spectroscopy quoted as $E_{\text {og }}=$ $1.02 \mathrm{ev}^{13,14}$.

\section{CONCLUSION}

In summary, we have presented a scheme to obtain the optical band-gap energy of different types of semiconductors by PAS technique The results agree very well with existing data. Finally we may add that the investigation of the pas can be expanded further into the infrared region of the spectrum giving more detailed information of other optical properties.

\section{ACKNOWLEDGMENTS}

The authors wish to thank Dr. Denis G.Francis David (Dassault Aviation - France) for helpful discussions in an earlier stage of this work. We are also greatful to Professor Donald Holcomb (Cornell University - USA) for the Si:P sample and Dr. Irajá $N$. Bandeira (INPE/LAS - Brazil) for the case and znSe samples. 


\section{REFERENCES}

[1] Mandelis A., Photoacoustic and Thermal Wave Phenomena in Semiconductors (North-Holland, New York, 1987).

[2] Eaves L., Vargas H. and Williams P.J., Appl. Phys Lett. 38 (1981) 768-770.

[3] Caetano de Souza J., Pinto Guedes G., de Brito Mota F., Pepe B.L., Francis David D.G., Veiga Salles Filho J.B., Ferreira da Silva A., Bandeira I.N., Scolfaro L.M.R., Martins J.M.V. and Leite J.R. "On the use of photoacoustic and photoconductivity techniques for investigating the optical properties of semiconductors". 5th Brazilian School on Semiconductor Physics, São Paulo 4-9 February 1991 (World Scientific, 1992) pp. 509-513.

[4] Zelaya-Angel O., Alvarado-Gil, J.J., Lozada-Morales, R., Vargas H. and Ferreira da Silva, A., Appl.Phys.Lett. 64 (1994) 291 - 293 .

[5] Sernelius B., Berggren K.-F., Jin Z:-C., Hamberg I. and Granquist C.G., Phys. Rev. B37, (1988) 10244-10248.

[6] Rosencwaig A., Physics Today, Sept (1975) 23-30.

[7] Ferreira da Silva, A., Phys. Rev. B48 (1993) 1921-1924.

[8] Caetano de Souza J. and Ferreira da Silva A., (unpublished) Eq. 1 was derived for direct gap crystalline semiconductors.

[9] Mahr H., Phys. Rev. 132 (1963) 1880 - 1889.

[10] Ferreira da Silva, A., da Cunha Lima I.C. and Parada N.J., J. Phys. Chem. Solids 42 (1981) 291-294.

[11] Mandelung 0., Landolt-Börnstein-Numerical Data and Functional Relationships in Science and Technology (New Series, Spring-Verlag, Berlin, 1987).

[12] Pankove J.I., Optical Processes in Semiconductors (Dover Publications, Inc. New York 1975) pp 412-413.

[13] Wagner J. and del Alamo J.A., J. Appl. Phys. 63 (1988) 425-429.

[14] Mott N.F. and Davis E.A., Electronic Processes in Non-Crystalline Materials (Claredon Press-oxford, 1971) p 238. For Si:P we have used the equation for indirect transition. 